\title{
STUDI SIFAT ELEKTROKIMIA SEL BATERAI SEKUNDER POUCHCELL LITHIUM ION LIFEPO4/GRAPHITE APLIKASI DAYA TINGGI
}

\author{
Achmad Subhan $^{1, \mathrm{a})}$, Bambang Prihandoko ${ }^{1}$ \\ ${ }^{1}$ Pusat Penelitian Fisika - LIPI komplek PUSPIPTEK, Tangerang Indonesia \\ Email: a)achm037@lipi.go.id
}

\begin{abstract}
Abstrak
Telah dilakukan pembuatan lembaran katoda dari serbuk LiFePO4 komersial dan anoda dari serbuk Graphite. Lembaran difabrikasi membentuk sel penuh baterai dengan tipe sampel uji berbentuk Pouchcell. Konfigurasi sel adalah LiFePO4//LiPF6//graphite, LiPF6 digunakan sebagai elektrolit cair. Karakterisasi sel dilakukan meliputi uji cyclic voltrametry, charge discharge dan EIS (electrochemical Impedance Spectroscopy. Nilai yg dihasilkan adalah kapasitas mencapai sekitar $80 \mathrm{mAh} / \mathrm{gr}$, dengan tegangan Voc stabil pada nilai $3.28 \mathrm{~V}$. Nilai discharge capacity yang bisa diambil hingga $5 \mathrm{C}$ lebih dari 40\%, dengan life cycle pada 50 siklus kehilangan kapasitas hanya kurang dari $5 \%$.
\end{abstract}

Kata-kata kunci: pouchcell, cyclic voltametry, electrochemical impedance spectroscopy, baterai high power.

\begin{abstract}
In this work, have been fabricated cathode electrode from LiFePO4 powder and anode from commercial Graphite powder. Full cell batteries fabricated in Pouchcell shaped test samples. Lithium ion cell configuration are LiFePO4 // LiPF6 // graphite, 1 M LiPF6 in EC/DEC is used as the liquid electrolyte. Cell batteries Perfomance characterized by some tests conducted on the cyclic voltrametry, charge-discharge and EIS (electrochemical impedance spectroscopy. The result value are the capacity reached approximately $80 \mathrm{mAh} / \mathrm{g}$, with the voltage Voc perfectly stable at $3.28 \mathrm{~V}$. The discharged capacity can be taken up to $5 \mathrm{C}$ almost over $40 \%$, with after 50 cycles for life cycle test the capacity loss is retain still $95 \%$ at $0.33 \mathrm{C}$.
\end{abstract}

Keywords: pouchcell, cyclic voltametry, electrochemical impedance spectroscopy, high power battery.

\section{PENDAHULUAN}

Baterai Li-ion adalah salah satu solusi sebagai penyimpan energi dan berkontribusi dalam mereduksi efek global warming (green-house gases). Dalam perkembangannya hingga saat ini penggunaan baterai sangat tidak bisa dilepaskan dari kehidupan sehari-hari. Hampir semua perangkat elektronik menggunakan baterai sebagai sumber penyimpan energinya. Saat ini baterai Li-ion yang paling banyak digunakan dalam berbagai aplikasi gadget. Dibandingkan dengan baterai lead acid ataupun Ni-MH, baterai Li-ion memiliki kelebihan yg cukup signifikan yaitu lebih ringan beratnya, memiliki kapasitas yg lebih besar, dan terkait lingkungan sangat kecil sifat racunya karena bebas dari logam berat seperti $\mathrm{Pb}$ dan merkuri $(\mathrm{Hg})$. Keunggulan lain dari baterai Li-ion adalah kemampuannya dalam penggunaan dgn aplikasi yang memerlukan daya besar. Baterai Li-ion dengan bahan katoda LiFePO4 saat ini banyak digunakan dalam aplikasi daya besar, salah satunya dalam mobil listrik 
[1,2]. Kemampuannya dalam aplikasi daya besar (fastdischarging) sangat diperlukan untuk menunjang kemampuan jarak tempuh mobil listrik. Saat ini daya jangkau mobil listrik berkisar 100 $\mathrm{km}$ untuk daya sebesar 20-100kWh [3-5]. Disamping itu juga diperlukan kemampuan baterai dengan kemampuan diisi dengan cepat pula (fastcharging). LiFePO4 saat ini diacu sebagai elektroda positif pada aplikasi daya tinggi seperti mobil listrik atau peralatan bengkel karena aman, robus, berharga murah[2]. Meskipun disisi lain memiliki kelemahan yaitu rendah tegangannya (3.45 V vs. $\mathrm{Li}+/ \mathrm{Li})$ dan kerapatan masa $(3.6 \mathrm{~g} / \mathrm{cm} 3)$ jika dibandingkan dengan material spinel lainnya $(\mathrm{LiCoO} 2$ memiliki $\sim 4 \mathrm{~V}$ vs. $\mathrm{Li}+/ \mathrm{Li}$ dan $5.1 \mathrm{~g} / \mathrm{cm} 3$ ). Dalam makalah ini akan disajikan hasil-hasil pembuatan lembaran katoda sehingga membentuk sel uji sifat elektrokimia dengan berbagai hasil uji sel baterai.

Sel baterai sekunder lithium-ion memiliki susunan sandwitch yang terdiri dari bagian anoda, katoda, elektrolit serta separator. Baterai sekunder memiliki kemampuan untuk dipakai-isi secara berulang-ulang dengan mekanisme interkalasi/deinterkalasi ion lithium pada struktur material katoda. Kemampuan bertransisi pada senyawa logam MaXb ( M-logam transisi, X = O,S,P) dengan struktur lapisan atau tunnel sehingga $\mathrm{Li}+$ ion ( satu atau lebih mol Li per mol MaXb) mampu menyusup secara reversible, tanpa merubah secara signifikan struktur kristalnya dengan kondisi pda suhu ruang (proses interkalasi) [4].

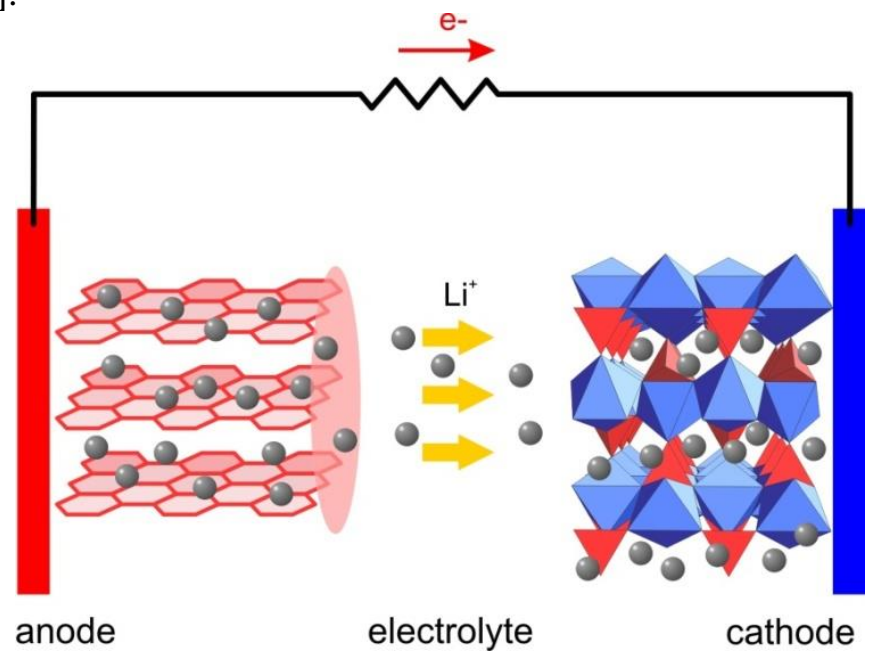

Gambar 1. Mekanisme proses interkalasi ion lithium dalam sel baterai lithium-ion[4].

Dalam proses ini, elemen dasar dari struktur Kristal tidak berubah, hanya sedikit membuat perubahan pada parameter kisi kristal. Kestabilan struktur selama proses sangat dipengaruhi oleh ikatan ionik dan kovalen antara atom $\mathrm{M}$ dan X. Persamaan transisi senyawa MaXb selama proses interkalasi dan deinterkalasi adalah sbb :

$\begin{array}{lccl}\text { Katoda }: & \mathrm{xLi}++\mathrm{xe}^{-}+\mathrm{MaXb} & \leftrightarrow & \text { LixMaXb } \\ \text { Anoda }: & \mathrm{C} 6+\mathrm{xLi}^{+}+\mathrm{xe}^{-} & \leftrightarrow & \text { LixC6 }\end{array}$

Selama proses interkalasi ini melibatkan sejumlah ion yg berpindah di dalam sel melalui elektrolit dan sejumlah electron yang sama bergerak melalui sirkuit luar. Parameter-parameter dalam baterai lithium LixC6/Li+/Li1-xMaXb meliputi kerapatan energi - per unit mass atau volume, bergantung dari emf sel dan kapasitasnya, ditentukan oleh sifat elektronik dan struktur kristal dari material elektrodanya. Begitu juga tegangan kerja antara elektroda bergantung pada properti katoda dan anoda yang digunakan.

\section{METODE PENELITIAN}

Sebelum dibuat lembaran, serbuk $\mathrm{LiFePO}_{4}$ dianalisa dengan XRD menggunakan Rigaku diffractometry pada $40 \mathrm{kV} 30 \mathrm{~mA}$, dengan $\mathrm{Cu} \mathrm{K \alpha}(\lambda=0.15406 \mathrm{~nm})$ dengan sudut $2 \Theta$ dari $20^{\circ}-80^{\circ}$ pada step $0.1^{0}$. Kemudian serbuk dibuat membentuk lembaran elektroda. Lembaran komposit katoda dibuat dari serbuk $\mathrm{LiFePO}_{4}$ sebagai material aktif. Binder polimer yang digunakan adalah 
polyvinylinene fluorides (PVDF), sedangkan acetylene black digunakan sebagai aditif karbon dengan komposisi berkisar 8.5:1:0.5. Slurry yg terbentuk kemudian dibuat menjadi lembaran $\mathrm{LiFePO}_{4}$. Fabrikasi lembaran dilakukan dengan alat doctor blade MSK-AFA-III (MTI). Dari lembaran katoda kemudian dibuat sampel baterai dalam bentuk pouchcell. Di dalam sel tersebut terdiri dari elektroda katoda//elekrolit//anoda, dengan elektrolit cair berupa 1M LiPF6 dalam pelarut ethylene carbonate/dimethyl carbonate (EC/DMC, 1:1) dengan anoda dari grafit MCMB. Aktifasi sel dilakukan di dalam glove box Vigor (gas Ar). Sifat-sifat elektrokimia dikarakterisasi dengan uji sel siklik voltametri, charge-discharge menggunakan WBCS 3000, dan uji impedansi komplek dengan memakai Autolab (PGSTAT302N + FRA32M). Tegangan uji sel diberikan antara 2.3V- 3.65V, dengan frekuensi antara $0.01 \mathrm{~Hz}-10 \mathrm{k} \mathrm{Hz}$.

\section{HASIL DAN PEMBAHASAN}

Pola difraksi X-ray diffraction pattern (XRD) serbuk LiFePO4 diperlihatkan pada gambar.2. Partikel $\mathrm{LiFePO}_{4}$ nampak memiliki struktur space group Pnma, orthorhombic olivine-type, dan bersesuaian dengan data ICDD 04-011-8634. Tidak ditemukan adanya fasa impurity seperti senyawa logam transisi $\mathrm{Li}_{3} \mathrm{PO}_{4}$ atau $\mathrm{FePO}_{4}$.

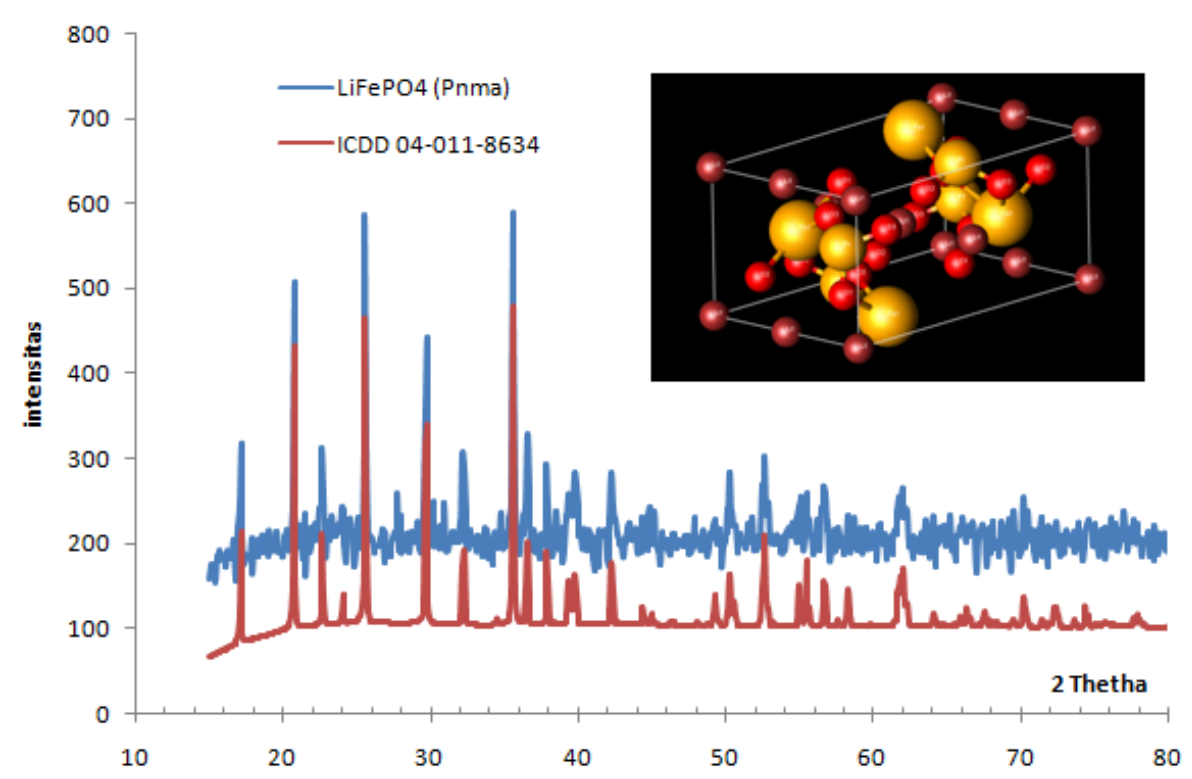

Gambar 2. Pola XRD dari serbuk $\mathrm{LiFePO}_{4}$.

Uji elektrokimia yang meliputi cyclic voltametry dan charge-discharge diberikan pada gambar 3 . Pada uji CV dilakukan dengan laju scanning pada $40 \mathrm{uV} / \mathrm{s}$ dengan rentang tegangan antara 2-3.8 V. Nampak dari grafik nilai tegangan oksidasi $\mathrm{Fe}^{2+} \leftrightarrow \mathrm{Fe}^{3+}$ terjadi pada tegangan $3.51 \mathrm{~V}$, sedangkan tegangan reduksi $\mathrm{Fe}^{3+} \leftrightarrow \mathrm{Fe}^{2+}$ terjadi pada 3.07 V. Dari kedua nilai ini maka nilai tegangan kerja sel baterai berada pada tegangan $3.30 \mathrm{~V}$. Pada scanning awal nampaknya ada satu peak kecil yang terjadi pada tegangan sekitar $2.3 \mathrm{~V}$ namun peak ini tidak muncul pada scanning berikutnya. 

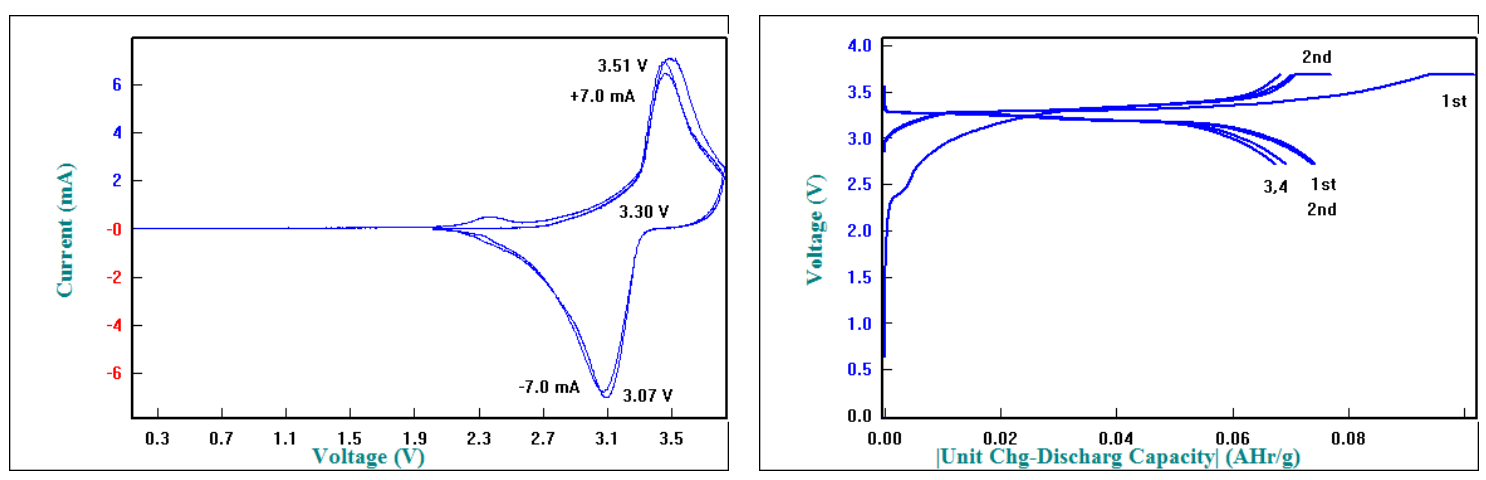

Gambar 3. (a). Hasil uji cyclic voltametry.

(b) Hasil uji charge-discharge dari pertama charging hingga charge-discharge ke -4.

Pola charge-discharge sel baterai pada siklus pertama hingga keempat diperlihatkan pada gambar 3(b). Nilai kapasitas charging pertama menghasilkan $102 \mathrm{mAh} / \mathrm{gr}$, dan pada discharging pertama mampu mencapai $\sim 75 \mathrm{mAh} / \mathrm{gr}$. Penurunan sebesar $25 \%$ ini sangat dipengaruhi oleh terjadinya lapisan SEI yang terbentuk pada siklus pertama kali baterai diaktifkan. Lapisan pasifatif SEI ini disisi lain berfungsi menjaga kestabilan sel karena mampu mencegah terjadinya dendritik lithium yang dapat mengakibatkan kerusakan sel akibat terjadinya hubungan langsung antara elektroda katoda dan anoda. Pada awal charging pertama, Nampak pola grafik yg sedikit membelok, yang terjadi pada tegangan sekitar $2.3 \mathrm{~V}$, dimana kapasitas baru terisi sedikit di awal. Nilai tegangan ini bersesuaian dengan peak pada grafik cylic voltametry, yaitu saat awal siklus yang memunculkan peak pada tegangan di sekitar $2.3 \mathrm{~V}$ juga. Nampaknya kehadiran peak awal ini mampu terdeteksi baik pada uji CV maupun uji charging discharge. Peak awal inihanya teramati pada siklus pertama saja, pada siklus berikutnya baik pada grafik CV maupun charging-discharging, peak ini tidak teramati lagi.

Uji charge/discharge menunjukkan kapasitas sel baterai mampu mencapai nilai yang cukup mendekati nilai praktikal $\mathrm{LiFePO}_{4}$, yaitu berkisar $100 \mathrm{mAh} / \mathrm{gr}$, dimana nilai teoritis $\mathrm{LiFePO}_{4}$ adalah $150 \mathrm{mAh} / \mathrm{gr}$ [5]. Kemampuan sel baterai pada kondisi beban yang lebih tinggi baik saat digunakan maupun saat dipakai sangat menentukan ketika akan diaplikasikan pada pemakaian daya besar seperti pada aplikasi mobil listrik. Beberapa persyaratan standar mensyaratkan nilai minimal sel baterai harus mampu dipakai hingga laju $-10 \mathrm{C}$ dan mampu diisi hingga laju $+4 \mathrm{C}$ tanpa mengalami kegagalan pada internal resistance dan tegangan kerjanya. Hasil uji fastcharging dan fastdischarging diperlihatkan pada gambar 4 dan gambar 5 .

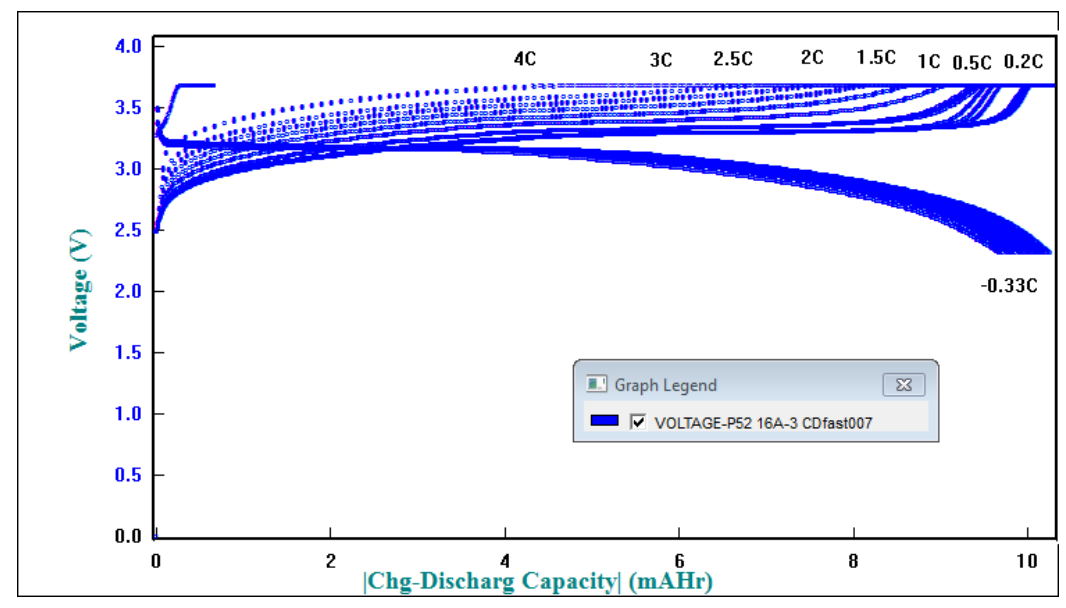

Gambar 4. Hasil uji fastcharging sel baterai dengan laju hingga +4C dengan discharging pada nilai tetap -0.33C. 


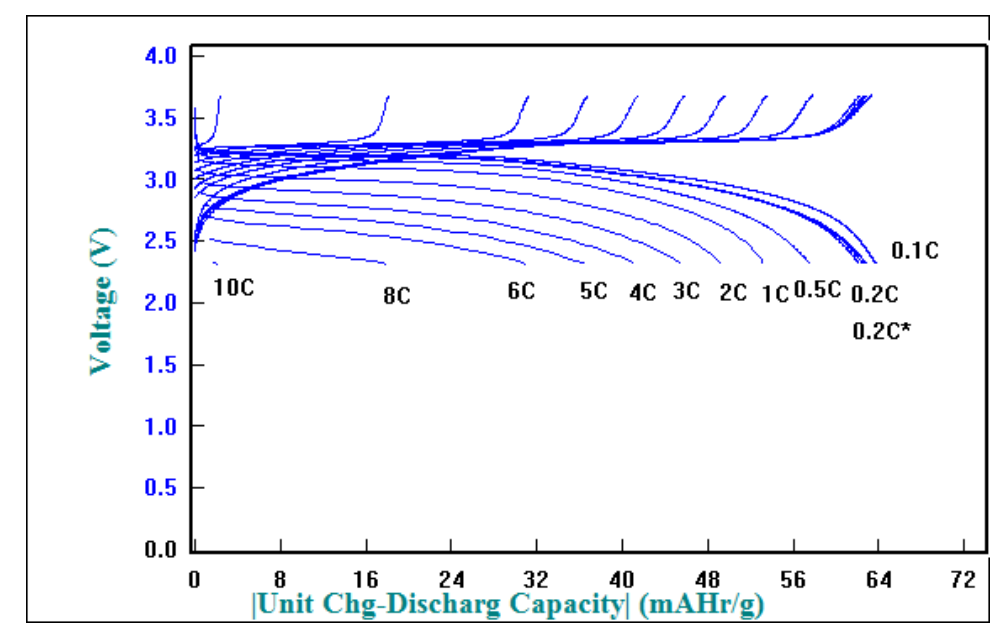

Gambar 5. Hasil uji fastdischarging sel baterai dengan laju discharging sampai -10C dan charging pada $+0.2 \mathrm{C}$.

Pada uji fastdischarging Nampak kapasitas sel baterai makin menurun dengan bertambahnya laju discharging. Penurunan kapasitas ini terjadi akibat kemampuan elektroda yg mengalami perpindahan ion dalam jumlah besar, namun mendapatkan hambatan akibat adanya kemampuan partikel dalam melakukan proses elektrokimia secara serentak. Laju hambatan ini semakin membesar dan cukup drastic saat laju pada -10C karena hanya kurang dari 5\% kapasitas baterai yang bisa diambil. Setelah laju mencapai $-10 \mathrm{C}$, baterai tetap kembali pada kondisi yang baik, ini ditandai dari uji berikutnya pada laju $0.2 \mathrm{C}^{*}$. Pada laju terakhir $0.2 \mathrm{C}^{*}$ Nampak kapasitas baterai mampu kembali pada kapasitas awal saat laju $0.2 \mathrm{C}$, yaitu masih memiliki kapasitas sekitar $65 \mathrm{mAh} / \mathrm{gr}$.

Kemampuan fastcharging dan fastdischarging ini sangat dipengaruhi oleh karakteristik hambatan dalam yang terjadi di dalam sel. Dari uji electrochemical imdepance spectroscopy (EIS) menunjukkan pola setengah lingkaran dengan garis warburg yang menandakan proses difusi ion terjadi pada antarmuka antara elektroda dan elektrolit. Gambar 6 menunjukkan hasil uji impedansi sel baterai pada kondisi awal $\left(1^{\text {st }}\right)$ baterai dan kondisi setelah uji fastcharging/fastdischarging.

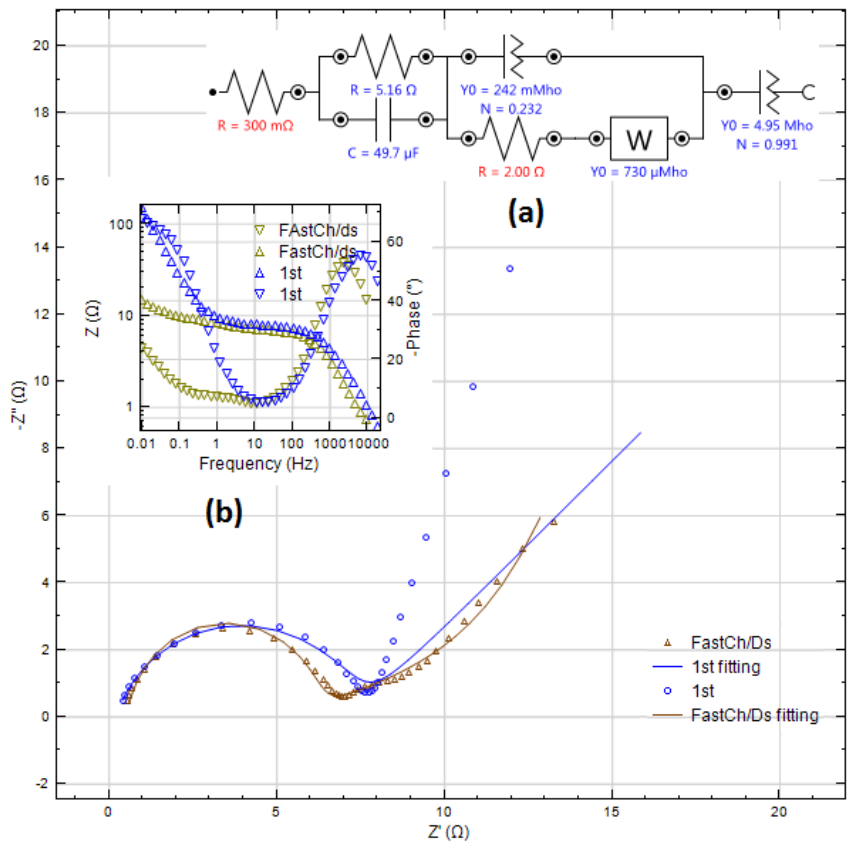

Gambar 6. Hasil uji impedansi komplek EIS sel baterai pada kondisi awal $1^{\text {st }}$ dan kondisi setelah uji fastcharging/discharging. (a). Rangkaian setara yang terdiri dari komponen [R(RC)(Q[RW])Q].

(b). Bodeplot $Z_{\text {total }}$ dan pergeseran fasa $(\Theta)$ dari sel baterai pada kondisi $1^{\text {st }}$ dan setelah uji fastcharging/discharging. 
Pola setengah lingkaran yang terbentuk tidak mengalami perubahan yang signifikan. Pada kondisi awal $1^{\text {st }}$ nampak garis difusi lebih tegak dibandingkan dengan setelah uji fastcharging/discharging. Kondisi saat awal menunjukkan proses difusi selama reaksi elektrokimia lebih mudah terjadi karena pada saat itu lapisan solid electrolyte interphase (SEI) belum terbentuk. Pada charging pertama pun Nampak hanya ada satu semicircle, sedangkan pada kondisi berikutnya menampakkan adanya semicircle kedua yang mengindikasikan lapisan SEI terbentuk di dalam interface pada elektroda anoda. Besaran hambatannya berkisar $\sim 2 \Omega$. Hambatan ini lebih kecil dibandingkan dengan semicircle pertama yg berkisar $\sim 6 \Omega$. Karakteristik hambatan dalam ini menentukan kemampuan sel baterai sehingga mampu diambil arusnya hingga laju -10C.

\section{SIMPULAN}

Sel baterai yang terbentuk dari lembaran katoda $\mathrm{LiFePO}_{4}$ dengan anoda grafit telah memiliki kemampuan sebagai sel baterai yang berpotensi diaplikasikan utk kebutuhan daya besar seperti mobil listrik. Sel baterai mampu memenuhi syarat minimal untuk fastcharging dan fastdischarging meskipun kapasitas yang masih bisa dipergunakan berkisar masing-masing $\sim 40 \%$ dan $\sim 50 \%$. Kapasitas sel baterai pada $0.2 \mathrm{C}$ mencapai $80 \mathrm{mAh} / \mathrm{gr}$ atau sekitar $264 \mathrm{Wh} / \mathrm{kg}$.

\section{REFERENSI}

[1] Naoki Nitta, Feixiang Wu, Jung Tae Lee, and Gleb Yushin, "Li-ion battery materials: present and future", Jurnal Materials TodayVolume 18, Number 5, June 2015, pp. 252264.

[2] Hendro Waluyo, Lukman Noerochiem, "Pengaruh Temperatur Hydrothermal terhadap Performa Elektrokimia LiFePO4 sebagai Katoda Baterai Ion Lithium Type Aqueous Elektrolit", Jurnal Teknik POMITTS Vol3, No.2, 2014, pp 237-242.

[3] Molenda Janina, "Composite Cathode Material for Li-Ion BatteriesBased on LiFePO4 System", intech, DOI: 10.5772/21635.

[4] C. Delacourt, P. Poizot, S. Levasseur, C. Masquelier, Electrochem. Solid-state Lett. 9, A352-A355 (2006).

[5] G. X. Wang, L. Yang, Y. Chen, J.. Wang, S. Bewlay, H.K. Liu, Electrochim Acta 50, 46494654 (2005).

[6] Cristian M. julien, KArim Zaghib, Alain Mauger, Henri Groult, "Advanced Electrodes for High Power Li-ion Batteries", Materials 2013, 6, 1028-1049; doi:10.3390/ma6031028

[7] J. Tarascon, M. , M. Armand, "Issues and challenges facing rechargeable lithium batteries", Nature, 414414 (November 2001) 359367 .

[8] Jing Lin, Daobin Mu, Ying Jin, Borong Wu, Yunfeng Ma, Feng Wu, “ Li-rich layered composite $\mathrm{Li}[\mathrm{Li} 0.2 \mathrm{Ni0} .2 \mathrm{Mn} 0.6] \mathrm{O} 2$ synthesized by a novel approach as cathode material for lithium ion battery", Journal Power Sources 230, 76-80, 2013. 